\title{
PENDIDIKAN KADER DAN PESANTREN MUALLIMIN MUHAMMADIYAH
} YOGYAKARTA

\author{
${ }^{1)}$ Azhar, ${ }^{2)}$ Wuradji, ${ }^{2)}$ Dwi Siswoyo \\ Universitas Gunung Rinjani Mataram, Universitas Ahmad Dahlan, Universitas Negeri Yogyakarta \\ azharfadila@gmail.com,wuradji43@gmail.com,dwisiswoyo@gmail.com
}

\begin{abstract}
Abstrak
Penelitian ini bertujuan untuk mengkaji, menganalisis, dan mendeskripsikan model pendidikan kader berbasis pesantren di Madrasah Muallimin Muhammadiyah Yogyakarta dan mengungkap kehidupan budaya Pondok Pesantren Muallimin Muhammadiyah Yogyakarta. Jenis penelitian ini adalah penelitian kualitatif dengan pendekatan studi kasus. Lokasi penelitian yaitu Madrasah Muallimin Muhammadiyah Yogyakarta. Pengambilan data menggunakan teknik pengamatan, wawancara mendalam, dan dokumen. Hasil menunjukkan bahwa Pendidikan kader di Madrasah Muallimin mempersiapkan kader kemanusiaan, keummatan, di masa mendatang yang kuat secara ketauhidan, kepribadian, dan keilmuan. Tahap awal menghasilkan kader ulama, pemimpin, mubalig dan pendidik melalui pendidikan dan pelatihan, belajar kemuhammadiyahan lebih mendalam, mencakup historis, organisatoris, dan ideologis, serta mampu memeragakan nilai muhammadiyah itu sendiri. Model pendidikan kader berbasis pesantren meliputi: (a) input yang menggunakan rapor, psikotes, representasi/keterwakilan daerah; (b) process yaitu memadukan sistem sekolah modern dan asrama pesantren melalui uswah (keteladanan). Strategi pengkaderan, Kurikulum yang dikembangkan untuk perubahan, (c) output: 95\% lulusan melanjutkan ke perguruan tinggi. Sebanyak $80 \%$ memasuki perguruan tinggi sesuai dengan harapan siswa. (d) outcome: alumninya berhasil dengan berbagai profesi dan mengembangkan amal usaha Muhammadiyah di daerah asalnya. (2) Kehidupan Pesantren Muallimin Muahammadiyah membangun: budaya kemandirian, budaya takwa, budaya akhlak karimah, budaya amar makruf nahi mungkar, serta berorientasi kepada keahlian dan keikhlasan.
\end{abstract}

Kata kunci: pendidikan kader, pesantren Muallimin Muhammadiyah

\section{CADRE EDUCATION AND MUALLIMIN MUHAMMADIYAH ISLAMIC BOARDING SCHOOL YOGYAKARTA}

\author{
${ }^{1)}$ Azhar, ${ }^{2)}$ Wuradji, ${ }^{2}$ Dwi Siswoyo \\ Universitas Gunung Rinjani Mataram, Universitas Ahmad Dahlan, Universitas Negeri Yogyakarta \\ azharfadila@gmail.com,wuradji43@gmail.com,dwisiswoyo@gmail.com
}

\begin{abstract}
This study aims to investigate, analyze, and describe a model of pesantren-based cadre education at Madrasah Muallimin Muhammadiyah Yogyakarta. Investigate life at pesantren Muallimin develops an autonomous culture. This was a qualitative study employing the casus study approach. The research setting was Madrasah Muallimin Muhammadiyah Yogyakarta. The data were collected through observations, indepth interviews, and document analysis. The results of this study are as follows. (1) Cadre education at Madrasah Muallimin aims to prepare humanitarian, nation, and Muslim cadres in the future who are strong in faith, personality, and scientific matters, producing ulema, leader, and educator cadres as agents of struggle missions and initiators, motivators, and actors of missionary activities through education and training, having Muhammadiyah-based package which is more intensive, covering the historical, organizational, and ideological scopes, in order that the santri/students are capable of manifesting Muhammadiyah itself. The model of pesantren-based cadre education consists: (a) input: it uses first the grade report, second psychological test and an interview, and fourth the representativeness of the region; $(b)$ process: Muallimin combines systems of the modern school and pondok pesantren dormitory using the uswah (good example), whose strategy is implemented, with the curriculum developed for changes; (c) output: 95 graduates, continue to study at higher education; $80 \%$ match the students expectation. (2) Life at pesantren Muallimin develops an autonomous culture, a culture of excellence in religious devotion through akhlak karimah, a culture of discipline and foreign language use, a culture of amar ma'ruf nahi mungkar, a culture of respecting the elder and loving the younger, habituation of Islamic life, implemented in the santri's personality intensively, and in dormitory life, each cadre is trained to habituate oneself, be organizationally involved, have expertise, and be sincere
\end{abstract}

Keywords: Cadre Education, Pesantren Muallimin Muhammadiyah 


\section{PENDAHULUAN}

Pesantren merupakan salah satu lembaga atau institusi pendidikan Islam tertua di Indonesia berkonstribusi sangat besar dalam mencerdaskan kehidupan bangsa. Hal ini sesuai dengan pernyataan pembukaan UndangUndang Dasar 1945. Pasal I UU Sisdiknas tahun 2003 menyatakan bahwa di antara tujuan pendidikan nasional adalah mengembangkan potensi peserta didik untuk memiliki kecerdasan, kepribadian dan berakhlak mulia (UU No 20 Tahun 2003, pasal 3). Dari pesantrenlah lahir tokoh-tokoh masyarakat, ulama, kaum intelektual, dan pemimpin-pemimpin bangsa.

Pendidikan pondok pesantern mengajarkan budi pekerti, sifat prilaku, karakter dan akhlak karimah lewat pembiasaan dalam kehidupan sehari-hari. Apabila dicermati lebih dalam, hampir semua nilai luhur dan adat tradisi Indonesia menyimpan berjuta nilai kearifan dan budi pekerti yang sangat luar biasa luhurnya, dan hal itu bahkan dikemukakan oleh banyaknya antropolog ternama dari dalam dan luar Indonesia. Bangsa Indonesia yang berwatak sosialistik-religius bercita-cita meraih kehidupan yang seimbang, serasi, dan selaras antara kehidupan batiniah dan kehidupan fisik materiil, nilai keagamaan.

Pendidikan dan kehidupan budaya pesantren melalui dakwah, dengan menanamkan kesadaran kolektif dan akhlak karimah melalui pembiasaan dalam kehidupan seharihari. Melalui pendidikan ditanamkan sebuah pemahaman dan keyakinan bahwa semua perkara yang dilakukan seseorang akan dimintai pertanggungjawabannya di sisi Allah Swt.

Moral santri adalah watak, tabiat, akhlak, atau kepribadian santri yang terbentuk dari hasil internalisasi berbagai kebajikan (virtues) yang diyakini dan digunakan sebagai landasan untuk cara pandang, berpikir, bersikap, dan bertindak. Kebajikan terdiri atas sejumlah nilai, moral, dan norma, seperti jujur, berani bertindak, dapat dipercaya, dan hormat kepada orang lain. Interaksi seseorang dengan orang lain menumbuhkan potensi dan kepribadian individu, karakter keluarga, karakter masyarakat dan bangsa.

Pengembangan kepribadian bangsa hanya dapat dilakukan melalui pengembangan kepribadian peserta didik melalui pendidikan hati, otak, dan fisik. Akan tetapi, karena ma- nusia hidup dalam ligkungan sosial dan budaya tertentu, maka pengembangan kepribadian seseorang hanya dapat dilakukan dalam lingkungan sosial dan budaya yang berangkutan. Artinya, pengembangan budaya dan kepribadian peserta didik hanya dapat dilakukan dalam suatu proses pendidikan yang tidak melepaskan peserta didik dari lingkungan sosial (Susanto, 2009, p. xi). Apabila peserta didik menjadi asing dari budaya terdekat, maka dia tidak mengenal dengan baik budaya bangsa dan dia tidak mengenal dirinya sebagai anggota budaya bangsa. Dalam situasi demikian, dia sangat rentan terhadap pengaruh budaya luar dan bahkan cenderung untuk menerima budaya luar tanpa proses pertimbangan (valueing). Kecenderungan itu terjadi karena tidak memiliki norma dan nilai budaya nasionalnya yang dapat digunakan sebagai dasar untuk melakukan pertimbangan valueing (Yasmadi,2002, p. 16).

Pembiasaan-pembiasan (habituasi) dalam kehidupan, seperti religius, jujur, disiplin, toleran, kerja keras, cinta damai, dan tanggung-jawab, perlu dimulai dari lingkup terkecil seperti keluarga sampai dengan cakupan yang lebih luas di masyarakat. Nilainilai tersebut tentunya perlu ditumbuhkembangkan yang pada akhirnya dapat membentuk pribadi dan karakter peserta didik yang selanjutnya merupakan pencerminan kehidupan budaya pondok pesantren, sebagai bagian dari budaya suatu bangsa yang besar, yang menjadikan budaya pesantren sebagai salah satu bagian setting sosial Islam (Habibulloh,1996, p. 11).

Menurut Abdulloh Mas'ud karakteristik utama budaya pesantren terdiri dari: (1) modeling identik dengan uswatun hasanah (contoh yang ideal) yang seharusnya diikuti dalam komunitas ini, Rasullullah Saw adalah panutan sentral; (2) cultural resistance, mempertahankan budaya dan tetap bersandar pada ajaran Islam sebagai konsekuensi logis dalam Islam; (3) budaya keilmuan yang tinggi, rujukan ideal keilmuan pesantren bersumber dari Alquran dan hadis. Dunia pesantren identik dengan dunia ilmu, proses pembelajaran, ustaz, santri, serta fasilitas tempat belajar mengajar (Mas'ud, 2002, p.97).

Muhammadiyah sebagai gerakan Islam, gerakan Dakwah dan Tajdid, tidak mungkin dilepas dari upaya-upaya pewarisan keyakinan dan cita-cita hidupnya, pewarisan 
kepribadiannya, kepada generasi muda, generasi penerus, pelangsung, dan penyempurna amal dan perjuangan Muhammadiyah. Semenjak awal kelahirannya usaha-usaha tersebut telah mendapatkan bentuknya sebagai sistem pengaderan dengan kekayaan tradisi Persyarikatan Muhammadiyah. Sistem tersebut telah berjalan puluhan tahun bahkan ratusan tahun, dengan berbagai dinamikanya, Namun demikian, akhir-akhir ini banyak disorot bahwa perkembangan Muhammadiyah yang begitu pesat, baik di bidang organisasi maupun badan-badan usaha yang menjadi stakeholder-nya, belum dapat diimbangi oleh jumlah dan mutu kader yang dihasilkannya. Apalagi apabila dikaitkan dengan keberadaan Muhammadiyah sebagai gerakan dakwah, begitu terasa minimnya kader-kader dakwah/ mubalig yang mumpuni dalam menjalankan dakwah amar makruf dan nahi munkar.

Menghadapi permasalahan-permasalah di atas diperlukan usaha-usaha yang serius untuk melakukan rekonstruksi pengaderan dai Muhammadiyah sesuai dengan visi perjungan Muhammadiyah dengan memperhatikan dinamika masyarakat yang senantiasa berubah dan berkembang. Sekolah kader Muallimin memiliki tugas melakukan rekonstruksi pengaderan dai Muhammadiyah, sekaligus pelaksana usaha-usaha pembinaan, pengembangan kader tahap awal dalam Muhammadiyah sebagai bagian dari tugas besarnya yakni melaksanakan dakwah, dan penyiaran ajaran Islam sesuai dengan prinsipprinsip pemahaman Muhammadiyah yang bersumber pada Alquran dan Sunnah.

Perlu dirumuskan konsep yang tepat untuk mengoptimalkan pendidikan kader dan peran pesantren, sehingga di masa depan pesantren dapat muncul sebagai salah satu pusat institusi pendidikan Islam tingkat menengah yang mengembangkan insan pesantren menuju terwujudnya generasi muda dan kader/muballig yang siap terjun ke masyarakat. Bagaimana hal ini diimplementasikan di pendidikan kader pondok pesantren Muallimin Yogyakarta, sebagai estapet dakwah illalloh, berilmu amaliyah, beramal ilmiyah, dan bertaqwa ilahiyah

Berdasarkan paparan tersebut, perlu diungkap/dikaji apakah pelaksanaan pendidikan kader berbasis pesantren di Madrasah Muallimin Muhammadiyah Yogyakarta berjalan sesuai dengan harapan atau tidak. Ter- dapat dua permasalahan dalam penelitian ini yaitu bagaimana model pendidikan kader di Madrasah Muallimin Muhammadiyah Yogyakarta dan bagaimana kehidupan budaya pondok pesantren Muallimin Muhamadiyah Yogyakarta.

\section{METODE PENELITIAN}

Penelitian dimaksudkan untuk mengungkap pelaksanaan/model pendidikan kader di Madrasah Muallimin dan kehidupan pesantren Muallimin Muhammadiyah Yogyakarta. Oleh karena itu, metode penelitian ini menggunakan pendekatan kualitatif jenis studi kasus. Studi kasus merupakan salah satu jenis pendekatan kualitatif yang menelaah sebuah" kasus" tertentu dalam konteks atau setting kehidupan nyata. John W. Creswell menyatakan peneliti studi kasus bisa memilih tipe penelitiannya berdasarkan tujuan, yakni studi kasus instrumental tunggal (yang berfokus pada satu isu atau persoalan tertentu), studi kasus kolektif (yang memanfaatkan beragam kasus untuk mengilustrasikan satu persoalan penting dari berbagai perspektif), studi kasus intrinsik (yang fokusnya adalah pada kasus itu sendiri, karena dianggap unik atau tidak biasa). Riset studi kasus mencakup studi tentang suatu kasus dalam kehidupan nyata, dalam konteks atau setting kontemporer (Yin, 2009. p.66).

Penelitian ini juga merupakan Grounded research yang tujuannya untuk memahami permasalahan yang muncul dalam suatu fenomena tertentu untuk menyusun, mengembangkan, dan merekonstruksikan teori berdasarkan data yang digali dari bawah secara langsung/induktif (Danim, 2006. p.97). Menurut tingkat ekspansinya penelitian ini terdiri atas deskriptif, komparatif, dan asosiatif, dengan melibatkan secara aktif (participatif) pelaku dalam kegiatan pendidikan dan kehidupan budaya pesantren, yakni: Pembina, pengasuh, pendamping, mudir, ustaz, karyawan, pamong asrama, musyrif dan santri, dengan fasilitas sarana dan prasarana.

Ditinjau dari jenis data pendekatan kualitatif, penelitian ini dilakukan melalui kajian terhadap perilaku yang terlibat di dalam pelaksanaan pendidikan dan kehidupan pondok pesantren di antaranya: Sistem penerimaan santri (recruitment), kurikulum/materi pembelajaran umum dan diniah, metode 
pembelajaran yang digunakan, aktivitas guru dan karyawan, aktivitas warga pondok pesantren, kehidupan asrama, formulasi kegiatan sehari-hari selama di pesantren kemitraan dan sumber daya yang yang dikaitkan dengan nilai-nilai Islam.

Penelitian ini bermaksud memberikan informasi yang akurat dan cermat tentang model pendidikan kader berbasis pesantren di Madrasah Muallimin Muhammadiyah Yogyakarta, sesuai dengan kenyataan di lapangan. Dengan menggunakan pendekatan ini dapat diungkapkan pendidikan dan kehidupan pesantren Muallimin Muhammadiyah Yogyakarta. Salah satu pertimbangan, mengapa pendekatan ini dipilih adalah: (1) masalah dan tujuan penelitian menuntut sejumlah informasi dan tindak lanjut; (2) masalah dan tujuan penelitian menuntut tindakan reflektif, kolaboratif, dan partisipatif berdasarkan situasi di lapangan (Arikunto,2006. p.74).

Salah satu ciri penelitian kualitatif adalah bersifat deskriptif. Data yang dikumpulkan lebih banyak berupa kata-kata atau gambar daripada dalam bentuk angka-angka. Menurut Arikunto, penelitian kualitatif mengandalkan manusia sebagai alat peneliti (human instrument), memanfaatkan metode kualitatif, analisis data secara induktif, mengarahkan sasaran penelitian pada usaha menemukan teori dari dasar, bersifat deskriptif, lebih mementingkan proses daripada hasil, membatasi studi tentang fokus, memilih seperangkat kriteria untuk menulis keabsahan data, rancangan penelitian bersifat sementara dan hasil penelitian disepakati oleh peneliti dan objek yang diteliti.

Dengan demikian, laporan penelitian berisi data untuk memberi gambaran penyajian laporan tersebut. Data tersebut berasal dari naskah wawancara, catatan lapangan, foto, dokumen pribadi, catatan atau memo, dan dokumen resmi lainnya. Dalam penulisan laporan analisis data setiap bagian ditelaah satu persatu melalui proses penggalian atau prilaku informasi (Sugiono, 2011. p.28).

Penelitian dilakukan di Pondok Pesantren Muallimin Muhammadiyah Yogyakarta, yang berkenaan dengan model pendidikan kader, dan kehidupan pesantren Muallimin. Waktu yang digunakan untuk penelitian ini terbagi dalam tiga tahap, yaitu: (1) perijinan penelitian pada bulan Juli 2014, (2) survey penelitian pada bulan Juli 2014 dan
(3) penelitian lapangan bulan Juli sampai dengan Nopember 2014 dilanjutkan analisis data dan penulisan laporan.

Subjek penelitian adalah sasaran penelitian yang dituju untuk diteliti oleh peneliti (Arikunto 2006. p.122). Untuk menentukan subjek penelitian, peneliti mempertimbangkan kedudukan masing-masing pihak untuk dijadikan subjek penelitian karena peneliti ingin menjaring sebanyak mungkin informasi dari berbagai sumber, disamping juga ingin menggali informasi secara mendalam, sehingga tujuan penelitian dapat tercapai.

Sumber data penelitian ini adalah warga pesantren yang berkenaan dengan kehidupan pesantren dan pendidikan kader. Selain data diperoleh dari warga belajar, juga diperoleh dari pihak penyelenggara program, dan kemitraan. Secara sederhana sumber data dalam penelitian ini berasal dari tiga sumber yaitu Warga Pondok Pesantren (ustaz, karyawan, mudir, staf, dan para santri), pembina, mitra pondok pesantren dan orang tua/wali santri.

Pengumpulan data dalam penelitian ini dilakukan dengan menggunakan beberapa teknik yaitu observasui, interview, dokumentasi, dan catatan lapangan. Teknik observasi digunakan untuk mengumpulkan data, mengenal aktivitas, pendidikan dan kehidupan budaya ponpes Muallimin Yogyakarta. Observasi adalah sebagai suatu pengamatan, pencatatan, secara sistematis terhadap gejala-gejala fenomena yang terjadi yang nampak pada objek penelitian. Sedang pengamatan terlibat adalah suatu pengamatan yang dilakukan oleh orang-orang yang terlibat secara aktif dalam peroses pelaksanaan tindakan.

Interviewu dapat dipandang sebagai salah satu teknik pengumpulan data dengan cara tanya jawab secara sistematik dan berlandaskan kepada tujuan penyelidikan. Teknik ini biasa digunakan sebagai sumber bagi penemuan hipotesis dalam menanggapi beragam interaksi sosio personal dan data yang bisa memberikan wawasan terhadap objek kajian.

Wawancara dilakukan dengan Kepala/mudir pesantren, beserta staf yang membidangi kegiatan unit pendidikan, ustaz, pamong/musrif, Trianggulasi diartikan sebagai teknik pengumpulan data yang bersifat menggabungkan dari berbagai teknik pengumpulan data dan sumber data yang telah ada. Bila 
peneliti melakukan pengumpulan data dengan trianggulasi, maka sebenarnya peneliti mengumpulkan data yang sekaligus menguji kredibilitas data, yaitu mengecek kredibilitas data dengan berbagai teknik pengumpulan data dan berbagai sumber data (Sugiyono, 2011, p. 16). Terkait hal itu, peneliti menggunakan tiga model triangulasi secara bergantian, yaitu trianggulasi sumber data, trianggulasi teknik pengumpulan data, dan trianggulasi waktu pengumpulan data. Dalam konteks ini, trianggulasi sumber data berfungsi untuk menguji kredibilitas data dengan cara mengecek data yang telah diperoleh melalui beberapa sumber. Trianggulasi teknik pengumpulan data berfungsi untuk menguji kredibilitas data dilakukan dengan cara mengecek data kepada sumber yang sama dengan teknik yang berbeda dan trianggulasi waktu pengumpulan data.

Dalam penelitian lapangan, dokumentasi digunakan sebagai sumber data karena dalam banyak hal dokumen sebagai sumber data dapat dimanfaatkan untuk menguji, menafsirkan, bahkan meramalkan. Dokumen ini dapat berupa dokumen peribadi yaitu catatan atau karangan seseorang secara tertulis tentang tindakan, pengalaman dan kepercayaan. Dalam dokumen pribadi, orang yang paling subjektif adalah pengalaman kepesantrenan. Oleh karena itu, barang kali saja mempelajari dokumen pribadi adalah salah satu cara yang paling dekat untuk memahami pengalaman kepesantrenan seeorang.

Catatan lapangan digunakan untuk menjaring data mengenai aktivitas warga belajar dan kondisi lapangan selama kegiatan berwirausha berlangsung. Instrumen yang digunakan adalah lembar-lembar kertas untuk merespons segala aktivitas warga belajar selama kegiatan penelitian berlangsung, yang telah ditandai dengan kode-kode tertentu guna mencatat dan mengelompokkan masalah-masalah tertentu yang ada di lapangan. Catatan lapangan dalam penelitian ini berkaitan tentang model pembelajaran yang diterapkan, pendekatan yang dilakukan, kurikulum (materi pelajaran), kegiatan warga pesantren.

Analisis data dalam penelitian ini menggunakan analisis data kualitatif. Menurut Moleong, analisis data kualitatif adalah upaya yang dilakukan dengan jalan bekerja dengan data, mengorganisasikan data, memilah- milahnya menjadi satuan yang dapat dikelola, mensintesiskannya, mencari dan menemukan pola, menemukan apa yang penting dan apa yang dipelajari, dan memutuskan apa yang dapat diceritakan kepada orang lain (Moleong, 2004. p.248).

\section{HASIL PENELITIAN DAN PEMBAHASAN}

Madrasah Muallimin Muhammadiyah Yogyakarta mempersiapkan kader kemanusiaan, kebangsaan, keummatan, di masa mendatang yang kuat secara ketauhidan, kepribadian, dan keilmuan. Pendidikan yang disiapkan adalah pendidikan yang unggul dan mampu menghasilkan kader ulama, pemimpin, dan pendidik sebagai pembawa misi gerakan Muhammadiyah, misi kejuangan dan perjuangan sebagai penggerak, penganjur dan pelaksana kegiatan dakwah melalui pendidikan, pelatihan dan pembiasaan sehari-hari di madrasah dan asrama pesantren. Sebagai sekolah kader, Muallimin memiliki paket pendidikan kemuhammadiyahan lebih mendalam, mencakup lingkup historis, organisatoris, dan ideologis, siswa mampu memeragakan nilai-nilai kemuhammadiyahan itu sendiri, cakap melakukan tugas-tugas persyarikatan masa depan. Moto Madrasah Muallimin "candradimuka kader masa depan" berarti Madrasah Muallimin menjadi tempat mempersiapkan kader kemanusiaan, kebangsaan, keummatan, di masa mendatang yang kuat secara ketauhidan, kepribadian, dan keilmuan.

Model pendidikan Kader di Madrasah Muallimin Muhammadiyah Yogyakarta, dalam penelitian ini meliputi beberapa sebagaimana berikut.

\section{Input Pendidikan Kader}

Proses penerimaan siswa baru menggunakan standar tes dan wawancara serta keterwakilan daerah dan rekomendasi pimpinan daerah. Penentuan peserta didik baru yang diterima, ditetapkan berdasarkan hasil tes seleksi calon peserta didik baru. Dengan pensyaratan sebagai berikut. (1) Nilai rata-rata rapor kelas IV sampai dengan kelas VI per semester minimal 80 (delapan puluh); (2) Foto copy piagam/sertifikat prestasi akademik/ nonakademik (jika ada dari tingkat kabupaten atau kota); (3) Menyerahkan surat rekomen- 
dasi atau mandat resmi, bukan rekomendasi sebagai utusan pimpinan daerah Muhammadiyah dan sanggup mengembalikan beasiswa jika ternyata tidak menyelesaikan sampai dengan tamat kelas VI Muallimin; dan (4) Mematuhi ketentuan berlaku sebagai siswa PDKP.

Untuk lebih mendalami bagaimana input Madrasah Muallimin Pendidikan Kader, penulis melakukan wawancara dengan PD I. Input penerimaan siswa:

Maahad biasa membuka pendaftaran jauh sebelum pengumuman UN karena tidak terlalu mengikat kepada aspek kognitif saja, pertama mereka datang tidak menggunakan ijazah, cukup menggunakan rapor, kedua seleksi melalui tes potensi akademik (TPA), psikotes, wawancara hasil penilaian secara objektif berdasarkan ranking kalau memang tidak lulus seleksi ya tidak diterima. Gelombang kedua tinggal menerima sisa, ada pertimbangan berapa persen menerima rekomendasi, itupun berdasarkan representasi wilayah. Kalau suatu daerah belum ada utusan, maka akan diterima dengan pertimbangan khusus, misalnya suatu wilayah yang minim kader dakwah, diterima dengan harapan sekembali ke daerahnya mereka dapat melanjutkan tugas dakwah dan memberikan pencerahan kepada masyarakat. (W VI/PD I/19-10-2014)

Input Muallimin hampir dari seluruh Indonesia, muali dari Aceh, Batam Riau, Pekan Baru, Jambi, Palembang, Lampung, Jakarta, Banten, Jawa Barat, Jawa Timur, Bali, NTB, NTT, Sulawesi, Maluku, Ternate, Papua, prosentase terbanyak dari Jawa Tengah dan DI Yogyakarta. Dari Luar jawa Persentase terbanyak dari Kalimatan timur, Kalimantan Utara dan Sulawesi.

Madrasah Muallimin Muhammadiyah Yogyakarta secara historis mendapat tempat yang sangat istimewa, terlebih ia didirikan langsung oleh K.H. Ahmad Dahlan dan direktur pertamanya adalah seorang pahlawan nasional tersebut. Sampai dengan sekarang pengelolaan madrasah muallimin berada di bawah PP Muhammadiyah dengan membentuk sebuah tim dengan nama Badan Pembina Madrasah Muallimin-Muallimat Muhammadiyah Yogyakarta, sehingga dukungan penuh diberikan oleh persyarikatan ini. Daftar jumlah pendaftar dari tahun 2011 sampai dengan tahun 2014 disajikan pada Tabel 1.
Tabel 1. Jumlah Pendaftar Santri Baru

\begin{tabular}{|c|c|c|c|c|}
\hline No & $\begin{array}{l}\text { Tahun } \\
\text { Ajaran }\end{array}$ & $\begin{array}{c}\text { Daya } \\
\text { Tampung }\end{array}$ & Pendaftar & Diterima \\
\hline 1 & 2011 & 238 & 477 & 238 \\
\hline 2 & 2012 & 238 & 511 & 238 \\
\hline 3 & 2013 & 255 & 660 & 255 \\
\hline 4 & 2014 & 238 & 737 & 238 \\
\hline \multicolumn{2}{|c|}{ Rata-rata } & 242 & 596 & 242 \\
\hline
\end{tabular}

Keterangan: Saat ini daya tampung madrasah baik ruang kelas maupun asrama sudah sampai ke titik maksimal

Sumber: Dokumen TU Muallimin

Adapun dukungan dari masyarakat luas khususnya warga Muhammadiyah semakin terlihat dari jumlah siswa yang mendaftar dan juga peran warga Muhammadiyah dalam pembangunan kembali gedung utama terlihat keikut sertaanya dalam berbagai bidang. Tentunya dukungan serta peran aktif persyarikatan dan masyarakat tidak hanya pada hal-hal yang terlihat saja, melainkan dukungan morilpun terus berdatangan untuk menguatkan Muallimin sebagai salah satu sekolah kader yang sangat diharpkan mampu mencetak kader-kader persyarikatan dan ummat di masa yang akan datang.

\section{Spesifikasi Pendidikan Kader}

Madrasah Muallimin Muhammadiyah Yogyakarta menerapkan spesifikasi pendidikan sebagai berikut. (1) Mata pelajaran AlIslam merupakan perpaduan antara kurikulum pondok pesantren dengan kurikulum madrasah Tsanawiyah dan Aliyah. Sedangkan materi disusun dalam bahasa Arab dengan merujuk kepada kitab-kitab standar berbahasa Arab yang mu'tabarah; (2) Mata pelajaran bahasa Arab dan Inggris, siswa diarahkan untuk memiliki kemampuan berbahasa secara aktif dalam kehidupan pesantren sehari-hari; (3) Pelajaran Al-Islam-kemuhammadiyahan sejumlah tokoh P.P. Muhammadiyah ikut mengasuh secara konperhensif dengan dilengkapi ilmu keguruan dan praktik dakwah, organisasi dan administrasi, serta latihan kepemimpinan sebagai bekal yang sangat berharga bagi santri/siswa ketika kelak berkiprah di dalam organisasi dan di tengahtengah masyarakat; (4) Mengembangkan program pendidikan keterampilan sesuai 
dengan minat dan bakat siswa, yang bersipat wajib dan pilihan. Prgoram keterampilan pilihan anatra lain: KIR, Jurnalistik kesenian (qira'ah, kaligrafi, nasyid, teater, dan olahraga (sepak bola, volley, bulu tangkis, tenis meja). Keterampilan wajib terdiri dari: komputer, beladiri, dan tapak suci; (5) Madrasah Aliyah mempunyai program agama yaitu program keagamaan (MAK-khusus Muallimin) dan program umum. Program umum terdiri dari jurusan IPA, IPS, Bahasa, yang di lengkapi dengan laboratorium fisika, kimia, biologi, bahasa, dan komputer. (Dokumen Mutu Madrasah Muallimin).

\section{Proses Pendidikan Kader}

Mengembangkan dan merencanakan proses pendidikan yang mengacu pada visi, misi kurikulum, kebijakan pemerintah, kebijakan persyarikatan. Muhammadiyah, kebijakan Madrasah, dan mempertimbangkan halhal lain yang diperlukan untuk dapat meningkatkan kualitas lulusan/tamatan. Perencanaan realisasi hasil proses pendidikan harus taat asas dengan persyaratan proses-proses lain dari sistem manajemen mutu. Menurut keterangan dari Pembantu Direktur I Bidang kurikulum, Dalam merencanakan realisasi hasil proses pendidikan, Madrasah menetapkan: (1) Sasaran mutu di madrasah dan persyaratan bagi lulusan; (2) Kebutuhan untuk menetapkan proses, dokumen dan sumber daya yang khas bagi hasil proses pendidikan; (3) Kegiatan verifikasi, validasi, pemantauan, pengukuran, infeksi dan uji khas (evaluasi belajar termasuk analisis kurikulum) dan kriteria keberterimaannya; (4) Rekaman yang diperlukan untuk memberikan bukti bahwa proses realisasi dan hasil proses pendidikan yang dihasilkan memenuhi persyaratan (W VIII/PD I/20-10-2014)

Proses pendidikan berkaitan dengan Stakeholders, Penetapan pensyaratan yang berkaitan dengan hasil proses pendidikan. (1) Madrasah menetapkan parsyaratan bagi calon siswa yang dapat diterima sebagai siswa muallimin dengan memperhatikan visi, misi, dan kebijakan madrasah serta kebijakan pemerintah, mencakup pensyaratan undangundang dan peraturan-peraturan yang beraku; (2) Madrasah menetapkan persyaratan stakeholder berdasrkan harapan stakeholder yang disesuaikan dengan visi, misi dan kebijakan madrasah serta kebijakan pemerintah, menca- kup pensyaratan undang-undang dan peraturan-peraturan yang berlaku; (3) Madrasah menetapkan persyaratan tambahan yang dibutuhkan. Hal-hal yang lebih rinci mengenai masalah ini diatur dalam SOP 72 tentang penerimaan peserta didik baru

Tinjauan persyaratan berkaitan dengan hasil proses pendidikan: (1) Setiap tahun madrasah akan meninjau dan menetapkan: (a) Persyaratan bagi calon siswa baru yang dapat diterima sebagai siswa madrasah dengan memperhatikan perubahan kebijakan madrasah, persyarikatan, dan madrasah; (b) Persyaratan stakeholder dengan memeperhatikan perubahan kebijakan madrasah dan harapan stakeholder;(c) Pensyaratan dan criteria kenaikan kelas dan tamat belajar dengan memperhatikan perubahan kebijakan dari madrasah, pensyaraikatan dan madrasah (2) Madrasah mengelola rekaman hasil tinjauan dan tindakan yang timbul; (3) Bila stakeholder tidak memberikan pernyataan tertulis tentang persyaratan, maka pernyataaan stakeholder harus ditegaskan oleh madrasah; (4) Bila pensyaratan hasil proses pendidikan diubah, madrasah harus memastikan bahwa dokumen yang sesuai harus juga diubadan personil yang sesuai dibuat peduli tentang pensyratan yang diubah.

Komunikasi dengan stakeholders Madrasah menetapkan dan menerapkan pengaturan yang efektif untuk mengadakan komunikasi dengan stakeholder sehingga perkembangan harapan dan tingkat kepuasan dapat dipantau secara terus menerus, komunikasi tersebut berkaitan dengan: (1) Informasi tentang calon peserta didik baru, proses pendidikan, hasil proses pendidikan dan tamatan/ lulusan; (2) Persyaratan pengelolaan proses pendidikan termasuk proses-proses yang terjadi; (3) Umpan balik dari stakeholder termasuk keluhan dari stakeholder (W VIII/D/2010-2014)

Untuk melakukan pengembangan SDM siswa di luar pengajaran formal sebagai program pokok, Madrasah Mu'allimin menyelenggarakan proses pendidikan kader dan pelatihan-pelatihan yang sistematis, terstruktur dan berkelanjutan. Pelatihan-pelatihan tersebut adalah: (1) Forum Orientasi Siswa (Fortasi) yang diperuntukkan bagi siswa baru; (2) Pelatihan Kader Terpadu Ikatan Pemuda Muhammadiyah (IPM), dikelompokkan menjadi dua kelompok: (1) Kelompok Kelas I-III 
dengan cara: (a). Menanamkan kesadaran nilai dan perilaku sehari-hari yang Islami; (b). Menanamkan jiwa keilmuan, kepemimpinan, dan kemasyarakatan; (c). Menanamkan kesadaran, kedewasaan, dan kemandirian hidup, terencana dan cita-cita; (2) Kelompok Kelas IV-VI dengan langkah-langkah sebagai berikut: (a) Membangun nalar intelektual kritis; (b) Memberikan kemampuan penunjang bagi jiwa; (c) kepemimpinan dan kepeloporan di masyarakat; (d) Taruna Melati, Salah satu Perkaderan di IPM yang berfungsi sebagai kaderisasi di IPM guna terciptanya kader penerus yang unggul, militan, dan berkualitas; (e) Training Of Trainers (TOT) mempersiapkan kemampuan siswa dalam menangani dan memfasilitasi kegiatan pelatihan yang diadakan; (f) Baitul Arqom dan Darul Arqom yaitu bentuk sistem perkaderan Muhammadiyah yang beriorientasi pada pembinaan ideologi dan kepemimpinan warga Muhammadiyah untuk menciptakan kesamaan dan kesatuan sikap, integritas, wawasan dan cara berpikir di kalangan siswa dalam melaksanakan misi Muhammadiyah; (g) Stadium General Stadium General bentuk penguatan ideologi untuk guru dan siswa oleh tokoh-tokoh nasional seperti: A. S. Ma'arif, M. Fadjar, Y. Ilyas, D. Rais, K. Basoni, K Muzakkir dan lain-lain

Untuk mengetahui Proses pendidikan kader lebih mendalam penulis melakukan wawancara dengan Salahudin, Selaku Direktur Muallimin, Beliau menyampaikan:

Mengacu kepada Muhammadiyah sesuai dengan visi dan misi Muhammadiyah yakni menyiapkan kader, kader di sini dibagi menjadi tiga pertama kader ulama, kader organisasi, dan guru/muallim: (1) Kader Ulama, bagimana para siswa dibekali tentang dasar-dasar menjadi ulama, dasar-dasar keislaman paling tidak ada usul fiqihnya, ilmu hadis, fikih, tafsir walaupun tidak terlalu mendalam; (2) Guru, iswa dibekali dengan metode mengajar, dedaktif metodik, dan membuat perangkat pemelajaran, dan praktik mengajar. Membiasakan mengajar di kelas 1 dan 2 atau seperti Mujannib kakak kelas yang membimbing adik kelasnya; dan (3) Kader organisasi: kaitan dengan organisasi Muhammadiyah seperti IPM, pelatihan-pelatian, ada taruna melati, baitul arqom, darul arqom untuk kelas 6. Latihan Kepemimpinan mulai dari kelas, asrama, organisasi santri/organtri, darul arqom dan mubaligh hijrah dan ada follow up-nya. (W VII/D/19-10-2014)

Guna mencari informasi pembanding tentang proses pendidikan kader, sebagai validasi kembali data dari informan penulis melakukan wawancara dengan PD I, beliau menyampaikan sebagai berikut.

Bagaimana Proses KBM pada pendidikan kader, pendidikan kader inklud pada program KBM dan program maahad, proses pendidikan kader berlangsung di kelas dan lebih diperdalam di maahad. Dengan materi muatan lokal di antaranya keguruan, keislaman dan kemuhammadiyahan, Pembentukan kader di maahad/asrama dan madrasah tidak mengenal dikotomi, terbukti ada anak pintar yang nilai kognitif rangking 1 lalu di maahad ibadahnya sering alpa atau akhlaknya tidak baik tidak naik kelas. Kriteria kelulusan dan kenaikan punya aturan normatif sendiri. Satu sisi kita masukkan aspek kognitif misal tidak boleh di bawah KKM bagi mata pelajaran wajib. Ada aturan normatifnya misalnya bidang akhlak berdasarkan penilaian 24 jam mendapatkan nilai B- maka tidak bisa naik kelas dan sudah disosialisasikan serta ditandatangani oleh orang tua wali bermeterai 6000 . (W VI/PD I/19-10-2014)

Bagaimana memanajemen proses pendidikan untuk mendapatkan hasil yang maksimal? Pertama berkenaan dengan pendidikan, tentu memperjuangkan tujuan pendidikan yang jelas. Tujuan pendidikan nasional pada umumnya dan tujuan pendidikan persyarikatan yang berkenaan beberapa materi, kemudian di-breakdown ke tim penyususn materi Ismuba; kedua tindak lanjutnya yang berhubungan dengan persyarikatan Muhammadiyah, sering mengundang dari PP aktif mengadakan seminar kemuhammadiyahan, Kajian sesuai manhaj, dialog kegiatan-kegiatan yang bersifat ilmiah; ketiga Muallimin dikatakan alumni syaratnya apabila lulus pendidikan dari Muallimin 6 tahun ada ujian kader yang menguji PP minimal PWM, itu pun tidak secara kelembagaan, sipatnya person; keempat Ada ujian kader di internal yang menguji guru-guru yang kompetens di bidang tersebut melalui wawancara. Bila tidak lulus ada kebijakan 1 bulan misalnya praktik khutbah di masjid, dibimbing oleh pembimbing yang sudah ada, kalau posisi tidak lulus hanya mendapatkan ijazah nasional. Untuk ijazah muallimin tidak (W VI/PD I/19-10-2014). 
Dikatakan alumni paling tidak mengenyam pendidikan 6 tahun di Muallimin, dan mendapat predikat lulus, Darul arqom adalah acara untuk kelas 6 dalam rangka memberi wawasan semangat atau motivasi dengan menghadirkan para alumni yang sudah berhasil, baik ekonomi, dosen, birokrat, seperti S Maarif. K. Bashori, Y Ilyas dsb. Prestasi Mualimin baik dalam bidang akademik maupun nonakademik membanggakan, sebagaimana yang disampaikan oleh bidang kesiswaan Pembantu Direktur III,

Prestasi Maahad Muallimin Alhamdulillah membanggakan, baik di tingkat provinsi, nasional bahkan internasional. Prestasi di bidang akademik misalnya kompetisi sains, olimpiade, lomba mapel dan informasi biasanya siswa yang lebih tahu karena setiap saat anak dapat mengakses internet. Sementara prestasi yang bersifat nonakademik lebih banyak, contohnya: tapak suci, Voly Ball, Tenis meja, lomba/membuat robot, kaitan denga penelitian karya ilmiah dan senantiasa menjuarai. Dan biasanya anak lebih tau karena biasa men-download setiap saat. (W VII/PDIII/20-10-2014).

Untuk revalidasi data dan informasi dari informan, penulis mewawancarai kepala urusan pengkaderan di Maahad Muallimin, beliau memberi penjelasan tentang proses pendidikan kader di Muallimin sebagai berikut.

Proses pendidikan kader: Anak dibiasakan untuk berlatih belajar terbiasa tampil di depan memberikan kultum, menyampaikan inisiatif mulai dari kelas 1 , dan itu gantian menjadi imam sholat, ia harus menerpa diri akan bacaan alqurannya, pakaiannnya, sikapnya, menjadi pemimpin mulai diri sendiri dan lingkungan Kelas 5 melatih mereka dengan masyarakat lebih dekat membina dan mengajar TPA Kelas 6 membiasakan dan melatih jadi Khotib Jumat di masyarakat. Ada target. Untuk kelas I, harus kegiatan perkaderan HW, kemah; Untuk kelas II, pramuka, tapak suci, jalan $20 \mathrm{~km}$ sebelumnya ada kegiatan tiga hari; Untuk kelas III baitul arqom proses pengkaderan memberikan gambaran tentang muallimin kita sebagai kader itu untuk apa sih, memberikan gambaran masih ada tiga tahun ke depan untuk pendidikan kader bagaimana ke depan; Untuk kelas IV Taruna melati awal pengkaderan di IPM dan itu wajib untuk ikut dasar kepemimpinan; Untuk kelas V wajib ikut organisasi siswa (IPM), muballigh hijrah miniamal 20 hari bisa di luar jawa kalimatan Sulawesi, jawa timur, cilcap dan sebagainya; dan Untuk kelas VI Darul Arqom dari proses pendidikan kader terakhir di Muallimin (W VII/Kaur PK/20-10-2014)

Dari sumber yang dihimpun oleh penulis, bahwa proses pendidikan kader di Maahad, Muallimin Yogyakarta, Menurut Kaur Pengkaderan, menerapkan prinsip:

\section{Output Pendidikan Kader}

Lulusan Madrasah Mu'allimin Muhammadiyah Yogyakarta telah banyak mengalami peningkatan, karena banyak yang melanjutkan ke Perguruan Tinggi baik Negeri maupun Swasta antara lain: Universitas Indonesia, ITB, Universitas Gadjah Mada, Universitas Negeri Yogyakarta, Universitas Sebelas Maret, Institut Pertanian Bogor, UIN Sunan Kalijaga, Universitas Padjajaran, Universitas Diponegoro, UNNES Semarang, Universitas Airlangga, Universitas Hasanuddin, Universitas Brawijaya, UIN Semarang, Universitas Ahmad Dahlan, Universitas Muhammadiyah Yogyakarta, Universitas Jendral Sudirman, Universitas Muhammadiyah Malang, Universitas Muhammadiyah Surakarta, ITS Surabaya, AMIKOM, ISI, UAD, UMY, UMSU, UII, LIPIA Jakarta dan lain-lain

Ada Alumni Mu'allimin yang melanjutkan ke Timur Tengah termasuk di Libya, Universitas Al Azhar, Kairo Mesir dan UTCI Malaysia. Alhamdulillah T.A 2011 / 2012 satu orang siswa Madrasah Mu'allimin Muhammadiyah Yogyakarta mendapatkan beasiswa dari Kemenag RI untuk studi lanjut di Turk Hava Kurumu University (Univ. Turkish Aeronautical Association) Fakultas Computer Enginnering atas nama Burhanuddin Ibrahim atas prestasi Internasional bidang Komputer di Belanda dan menjadi Duta Kebudayaan di Jepang.

Setelah santri menyelesaikan program-program dan seluruh rangkaian kegiatan pendidikan kader di Muallimin Muhammadiyah Yogyakarta yang telah tamat diharapkan mempunyai kualifikasi kader sebgai berikut: (1). Berkepribadian muslim yang berakhlak mulia dan taat dalam menjalankan perintah-perintah Allah dan Rasulnya serta menjauhi segala larangannya; (2) Siap terjun di masyarakat sebagai mujahid dakwah dan pendidik; (3) Mempunyai kemampuan mem- 
perdalam agama melalui kitab-kitab standar berbahasa Arab bagi siswa jurusan keagamaan, dan memperdalam ilmu pengetahuan umum bagi siswa jurusan umum; (4) Dapat melanjutkan pendidikan ke berbagai Perguruan Tinggi Agama dan Umum, di dalam negeri maupun luar negeri.

Penelusuran alumni melalui wawancara, dengan BK dan Pembantu Direktur III Bidang Kesiswaan sebagai berikut.

Alumni Muallimin 95\% melanjutkan studi atau kuliah, dari keseluruhan lulusan setiap tahunnya, $80 \%$ melanjutkan studi sesuai dengan harapan santri yang bersangkutan, ketika mereka kuliah mereka turut mewarnai, bukan diwarnai tempat tinggal mempengaruhi, tinggal di mesjid menjadi pengurus masjid, di kos-kosan menjadi pimpian kos kalau di kampus rata-rata menjadi pengurus/pemimpin di organisasi kampus apakah itu IMM, HMI, sebagian besar aktifis kampus di berbagai organisasi mahasiswa. Targetnya: bisa jadi kader di masyarakat jadi kader di masyarakat /persyaraikatan, minimal memberi pengaruh atau mewarnai kehidupan di masyarakat, memberikan pencerahan bukan ikut-ikutan. (W VIII/PD III-BK/20-10-2014)

Seiring dengan perkembangan dan tuntutan zaman maka Muallimin tidak hanya menjadi guru lebih dari itu ada yang menjadi hakim, dokter jadi pengacara dan sebagainya, memberi manfaat di masyarakat. Pendidikan kader sejak di asrama, ditanamkan jiwa kepemimpinan kaderlah anak-anak menjadi pemimpin, mulai dari pemimpin kamar, asrama, kelas, organisasi santri dan cukup banyak memberikan bekal kepada mereka memberi pelatihan, baru terasa ketika mereka kelas aliyah kelas IV dan V dan membekas ketika telah terjun di masyarakat. Lulusan Muallimin tolok ukur keberhasilannya kompetnsi lulus baca Alquran, khutbah jumat, lulus kader, muballigh hijrah, bisa memebrikan pencerahan kepada masyarakat bukan-ikut-ikutan. Kepada tahayyul, khurapat dan bid'ah.

Strategi untuk mendapatkan hasil kader terbaik adalah: Seleksi Alquran, kemampuan inteligensi untuk mengikuti 48 mapel dibina di asrama, disiplin, pengertian dengan teman sekamar, memelihara milik pribadi memperhatikan hak orang lain, menaati peraturan. Perbandingan musrif 1 berbanding 40 musrif rata-rata sudah dewasa ada sarjana, atau kuliyah tingkat akhir. 1 kamar 16 orang 8 ranjang tingkat 2 dan 2 kamar mandi. Seting asrama yang baru dibangun, 1 kamar untk 6 orang, satu kamar madi. Anak diarahkan disiplin mengarahkan dan mengingaktkan anak untuk mengatur waktu. Kegitan asrama setelah subuh, setelah magrib, dan bakda isya tetap ditanakman kepada mereka tetap menghafal dan kepintaran kecerdasan dari situ target menghafal. Untuk penuhi target pelajaran sekolah pendampingan pelajaran usatz, musrif, tutor sebaya, mengarahkan anak untuk bisa bagi waktu anak-anak bisa menikmati, dengan kondisi seperti ini mereka mengondisikan diri sendiri. (W VII/PD IV/20-102014). Sore hari ada ekstrakurikulr bersifat rekreatif dan menghibu serta olah raga.

\section{Outcome Pendidikan Kader}

Madrasah Muallimin secara kelembagaan telah berdiri sejak tahun 1920, ini berarti apabila jenjang pendidikannya selama 6 (enam) tahun, maka sejak tahun 1926 telah meluluskan kader 88 (delapan puluh delapan) angkatan. Para alumninya telah menyebar ke seluruh wilayah Indonesia dengan berbagai profesi, seperti politisi, sejarawan, pendidik, dai, penegak hukum, dan lain-lain. Tidak sedikit para alumninya yang langsung terjun di tengah masyarakat sebagai pelangsung dan penyempurna amal usaha Muhammadiyah di daerah asalnya. Tokoh-tokoh besar yang telah menyelesaikan belajarnya di Muallimin anatara lain, Prof. K.H. K Mudzakir, Prof. Dr. S Maarif, KH. A.R. Fakhrudin, Prof. Drs. H. A. Abdurrohman, dan lain-lain. Ikatan resmi para alumni ini tergabung dalam IKAMMM (Ikatan Keluarga Abiturient Madrasah Muallimin Muallimat Muhammadiyah).

Pengkaderan, menerapkan spirit dari pendiri Muallimin KH Ahmad Dahlan yaitu prinsip Jadilah Insinyur, jadilah dokter, jadilah apapun maka kembalilah ke Muhammadiyah pendidikan umum masuk dan pendidikan agama, masuklah sebagai seorang kader memberikan pencerahan kepada persyarikatan, kepada msyarakat memberikan perubahan kepada masyiarakat, profesi apapun dia, ia bermanfaat di masyarakat, Islam secara umum, bermanfaat kepada masyarakat, awalawal berdiri untuk mencetak guru sehingga dikirim ke aderah-daerah. (W VII/Kaur PK/20-10-2014)

Lebih lanjut Kepala urusan pengaderan menambahkan bahwa, untuk menerjemah- 
kan spirit pendiri, Muallimin mengambil kebijakan sebagai berikut: kita buka jurusan Umum, IPA, IPS, Bahasa karena tidak semua anak menjadi da'i tetap ditanamakan dasar-dasar/pondasi agama, tidak semua anak berkeinginan jadi ulama (W VII/Kaur PK/2010-2014)

Menurut penulis keberhasilan pengaderan yang ada di Madrasah Muallimin karena spirit dari pendiri Muallimin, kesadaran kolektif warga Muhammadiyah, pengelolaan dan menejmen yang visioner, komitmen yang tinggi, kesadaran keberagamaan yang memadai, pengembangan kurikulum untuk perubahan dan dakwah, serta orientasi kepada keseimbangan ilmu dinul Islam dan pengetahuan umum.

\section{Kehidupan Budaya Pesantren Muallimin}

Muhammadiyah merupakan gerakan Islam yang mengupayakan terwujudnya kehidupan budaya masyarakat yang didasarkan pada nilai-nilai dasar Tauhid yang murni dan akhlak karimah yang bersumber pada Alquran dan As-sunnah. Muhammadiyah meyakini bahwa dengan menegakkan dan menjunjung tinggi tauhid yang murni dan akhlak karimah dapat menyelamatkan dan mengangkat derajat hidup manusia, baik di dunia maupun di akhirat.

Untuk mewujudkan idealitas tersebut. Pondok Pesantren Muallimin Muhammadiyah memandang perlu dilakukannya upaya yang sungguh-sungguh sebagai proses transformasi nilai-nilai ajaran Islam secara sistematik, terencana, melalui kegiatan pendidikan. Pendidikan menjadi sarana penting untuk menumbuhkan manusia memiliki cara pandang, karakter dan keterampilan dalam menjalankan fungsinya sebagai khalifatullah fil ardi sehingga mampu menjadi rahmat bagi seluruh alam.

Kehidupan budaya pesantren Muallimin Muhammadiyah didasarkan pada semangat tauhid, keikhlasan, kejujuran, akhlak karimah, ukhuwah atau solidaritas, harapan (roja'), ketaatan (khauf), keadilan, tanggung jawab, kesabaran, rasionalitas, disiplin, dan semangat amar ma'ruf nahi mungkar. Nilainilai dasar universal tersebut menjadi ruh dalam setiap gerak langkah dan aktivitas seharihari di pesantren Muallimin Muhammadiyah.

Kehidupan budaya pesantren Muallimin, Membangun budaya kemandirian me- lalui etos kerja dan kejujuran yang tinggi, membangun budaya keunggulan di bidang ketakwaan melalui akhlak karimah dan intelektualitas melalui budaya disiplin dan berbahasa asing, membangun budaya amar makruf nahi mungkar melalui gerakan dakwah jamaah, menumbuhkan budaya tampil percaya diri antri, solidaritas, kebersamaan, infak, kerja bakti, tanggung jawab, bersih, kepemimpinan, keamanan dan kenyamanan, budaya menghormati yang tua dan menyayangi yang lebih muda, ikatan emosional yang kuat antara pamong musrif dengan santri, budaya doktrin untuk (kelas 1, 2, 3), budaya demokratis untuk (kleas 4 dan 5), budaya shering untuk (kelas 6) duduk bersama membaur (kapan musyrif memposisikan diri sebagai ayah, kakak, ibu, teman, ketika anak terbuka itulah suatu keberhasilan menerima aturan tapi mendongkol).

Santri merasakan kebanggaan tersendiri sekolah di Muallimin karena langsung di bawah pimpinan pusat Muhammadiyah, pembiasan (habituasi) dalam kehidupan islami, jujur, toleran, kerja keras, cinta damai, membentuk pribadi dan karakter santri merupakan cermin kehidupan/budaya pesantren, asrama merupakan penunjng seluruh kegiatan pendidikan kader di muallimin, di asramalah proses pendidikan islami yang sebenarnya berlangsung, melalui pendidikan, pelatihan, bimbingan, pengalaman dan pembiasaan. Agama diimplementasikan dalam pribadi santri, sehingga terjadilah proses internalisasi secara intensif dibawa bimbingan musyrif dan pamong yang tinggal bersama santri, dengan semangat amar ma'ruf nahi mungkar.

Dalam kehidupan asrama itulah setiap kader dilatih dan dibiasakan cara berpikir, sikap mental, kesadaran beragama dan berorganisasi, keahlian serta keikhlasan berpusat pada: (a) pikiran selalu berpandangan dakwah (dakwah oriented); (b) Sikap mental, selalu berjiwa dakwah (dakwah minded); (c) Kesadaran beragama, Islam adalah ruh yang menggerakkan setiap amal perbuatan yang dikerjakan; (d) Kesadaran berorganisasi: Komitmen, kerja sama, saling mengisi, tanggung jawab. Pesantren Muallimin sebagai wadah alat perjuangan untuk mengamalkan dan memperjuangkan Islam; (e) Keahlian, memiliki wawasan, menguasai teknologi, media informasi sebagai bagian strategi dakwah. 
Menurut pengamatan dan hasil wawancara penulis dengan Kepala Urusan Pesantren lebih lanjut mengemukakan bahwa, dengan semangat QS Al-Imron 104 dan 110, Pondok Pesantren Muallimin dapat memainkan peran dakwah Islam yang berdimensi rehumanisasi dan emansipasi (al-amr bilma'ruf), liberasi (wal nahyi anil-mungkar) dan Transedensi (watukminu nabillah) yang memiliki keseimbangan antara hablumminalloh dan hablumminannas). Dengan kata kata lain pola hidup dan kehidupan budaya Pondok pesantren Muallimin Muhammadiyah bisa dijadikan sebagai upaya dalam mengaktualisasikan nilai-nilai Islam demi lebih meningkatkan kualitas hidup santri, masyarakat ketika mereka terjun di masyarakat, dan pada gilirannya kepada ummat Islam pada umumnya. (WN/Kaur Pesantren/19-10-2014).

\section{SIMPULAN DAN SARAN}

\section{Simpulan}

Model pendidikan kader di Madrasah Muallimin Muhammadiyah Yogyakarta, mempersiapkan kader kemanusiaan, keumatan, di masa mendatang yang kuat secara ketauhidan, kepribadian, dan keilmuan. Sebagai tahap awal untuk menghasilkan kader pemimpin, dan pendidik sebagai pembawa misi gerakan, misi kejuangan dan perjuangan sebagai penggerak, penganjur dan pelaksana kegiatan dakwah melalui pendidikan, pelatihan dan pembiasaan sehari-hari di madrasah dan asrama pesantren. Sebagai sekolah kader muallimin memiliki paket pendidikan kemuhammadiyahan lebih mendalam, mencakup lingkup historis, organisatoris, dan ideologis, siswa dibiasakan memeragakan nilai-nilai kemuhammadiyahan itu sendiri, agar cakap melakukan tugas-tugas pensyarikatan di masa yang akan datang, mereka dibekali keterampilan dan kepemimpinan.

Model pendidikan kader berbasis pesantren dalam penelitian ini meliputi: (a) input: Muallimin membuka pendaptaran siswa baru jauh sebelum UN, menggunakan rapor, tes potensi akademik, psikotes, representasi/ keterwakilan daerah; ((b) process: Madrasah Muallimin memadukan sistem sekolah modern dan asrama pesantren, mengembangkan sistem boarding school, life long education yang dilakukan di maskan/asrama dengan pendekatan uswah (keteladanan) Kurikulum yang dikembangkan untuk perubahan, dengan teknik (crossing curriculum dan KTSP). Proses pengaderan yang dilakukan berupa pembinaan dalam oraganisasi Muhamadiyah, membiasakan berdiskusi kepemimpinan, (c) Output: $95 \%$ lulusan melanjutkan ke perguruan tinggi, dapat memasuki perguruan tinggi sesuai dengan harapan siswa sebanyak $80 \%$ dari jumlah kelulusan. (d) Outcome: Para alumninya telah menyebar ke seluruh Indonesia dengan berbagai profesi, sebagai pelangsung dan penyempurna amal usaha Muhammadiyah di daerah asalnya.

Kehidupan budaya pesantren Muallimin. Membangun budaya kemandirian melalui kejujuran yang tinggi, membangun budaya keunggulan di bidang ketakwaan melalui akhlak karimah dan intelektualitas melalui budaya disiplin dan berbahasa asing, membangun budaya amar makruf nahi mungkar melalui gerakan dakwah jam'i, menumbuhkan budaya tampil percaya diri, solidaritas, kebersamaan, infaq jam 'i, kerja bakti, tanggung jawab, bersih, kepemimpinan, keamanan dan kenyamanan, budaya menghormati kaum tua dan menyayangi yang lebih muda, hubungan emosional yang kuat antara pamong, musrif, dengan santri, budaya doktrin untuk (kelas 1-3), budaya demokratis untuk (kleas 4 dan 5), budaya sharing untuk (kelas 6) pembiasan (habituasi) dalam kehidupan Islami, kehidupan asrama merupakan penunjang seluruh kegiatan pendidikan kader di Muallimin, dengan semangat amar ma'ruf nahi mungkar. Dalam kehidupan asrama setiap kader melatih membiasakan cara berpikir, sikap mental, kesadaran beragama, berorganisasi, keahlian, serta keikhlasan

\section{Saran}

Model pendidikan kader, untuk input perlu program mercusuar Madrasah Muallimin; Proses, perlu dipetakan siswa yang cerdas dan baik, diarahkan sesuai dengan bakat dan minat, baik bidang akademik maupun nonakademik, kemudian ditunjuk/dikawal oleh bagian yang kompeten di bidang keahliannya sehingga, dapat mewujudkan harapan kader. Untuk kader yang agak kurang di akademik diperlukan klinik belajar; output, untuk mempermudah melanjutkan studi, sebaiknya ada Mo-U dengan perguruan tinggi terutama perguruan tinggi di luar negeri, 
misalnya, terakreditasi/muadalah dengan Universitas di Timur Tengah untuk jurusan diniah, dan Eropa atau lainnya untuk jurusan umum/sains; outkam perlu ada penelusuran alumni secara periodik. Kinerja Ikatan kader alumni yang ada perlu dimaksimalkan, mengingat gema almamater menjadi besar karena alumni. Alumni agar mempertahankan tekad untuk melatih diri sebagai panutan umat sehingga betul-betul menjadi warasatul anbiaya yang selalu ditunggu umat Islam untuk meneruskan perjuangan.

Menumbuhkan kesadaran kolektif dimulai dari kesadaran masing-masing individu untuk menjalankan semua aturan dan tata tertib di asrama, sehingga lebih humanis, bukan atas dasar tekanan ataupun keterpaksaan. Untuk memaksimalkan proses pendidikan kader perlu pendampingan lebih selama di asrama, sehingga, mutu layanan dapat ditingkatkan, dan semua aktivitas berjalan sesuai dengan jadwal guna mencapai tujuan yang telah ditetapkan.

Perlu mendapat perhatian dari kurikulum, struktur kurikulum gemuk, memberatkan karena beban yang hampir dua kali lipat yang harus diselesaikan siswa dalam satu waktu, siswa harus menempuh 23-26 mata pelajaran dari setiap jenjang, sementara sekolah lain hanya 14-16 mata pelajaran. Perlu proses penyempurnaan terus-menerus agar format kurikulum madrasah menjadi holistic dan konprehensif.

\section{DAFTAR PUSTAKA}

Arikunto, S. (2006). Prosedur penelitian suatu pendekatan praktek. Jakarta: Rineka Cipta
Chirzin.MH. (1986). Agama dan ilmu dalam pesantren. Jakarta: LP3ES

Creswell, J. W. (2014). Penelitian kualitatif \& desain riset. Yogyakarta: Pustaka Pelajar.

Danim, S. (2006). Agenda pembaruan system pendidikan. Yogyakarta: Pustaka Pelajar

Dhofier, Z. (1994). Tradisi pesantren. Jakarta: LP3ES

Geertz, C. (1995). Kebudayaan dan agama. Yogyakarta: Kanisius.

Habibulloh, Z (1996). Moralitas pendidikan pesantren. Yogyakarta: LKPSM

Jenice, M \& Guba (1994). Critical issue in qualitative reseach methods. California: SAGE Publication. Inc.

Mas'ud, A. (2002). Dinamika pesantren dan madrasah. Yogyakarta: Pustaka Pelajar.

Moeleong, L.J. (2005). Metodologi penelitian kualitatif. Bandung: PT. Remaja Rosdakarya

Sugiyono. (2011). Metodologi penelitian kuantitatif, kualitatif dan $R \& D$. Bandung:

Yasmadi.(2002). Modernisasi pesantren. Jakarta: Ciputat Press

Yin. R.K. (2009). Studi kasus desain dan metode. Jakarta: Raja Grapindo Persada

Republik Indonesia. Undang-Undang no 20 Tahun 20013 tentang Sitem Pendidikan Nasional.

Susanto,A. (2009). Menuju jati diri pendidikan yang mengindonesia. Yogyakarta: Gajah Mada University Press. 